\title{
Per L. Bylund, The Problem of Production: A New Theory of the Firm
}

\section{New York: Routledge, 2016. viii +178 pages. 140 USD (hardback)}

\author{
Henrique Schneider ${ }^{1}$
}

Accepted: 8 December 2020 /Published online: 19 January 2021

(C) The Author(s) 2021

If the market is so efficient, why are there firms? This question is almost as old as economics itself. It can be answered with an analysis of what a firm does. Rather surprisingly, this direct approach is seldom taken. Instead, economists have looked at how the firm is organized, how it plans, or which single variable it optimizes. Bylund, however, opts for the direct approach. When the author asks about the problem of production, he looks at what firms do, i.e. he puts the firm's core activity in the center of his inquiry. While doing so, he also responds the overarching question about why are there firms in the first place.

In Bylund's view, firms are vehicles for super-specialized innovation; they channel novel products into the market process. As such, they are not something outside, but they are an occurrence of the market. The author reaches this conclusion by examining what a firm does from a point of view based in Austrian economics complemented with insights gained from research on strategy and management.

In summary, the Bylund argument goes: The firm is the entrepreneur-as-innovator's way to organize specialization to a degree that cannot be found in market processes. This is not due to the market-mechanism, but to the function of innovation itself. There is something new that cannot be produced by the market in its status quo, because the market does not know of it. The entrepreneur profits from exogenous changes converting them into opportunities, profiting when introducing these opportunities as novel products into market processes. It is the entrepreneur-as-innovator who organizes the production of this novel good while taking on all risks associated with it and bridging the time it needs to become market-prone. The firm, after having served as super-specialized producer of the novelty, is also the vector for releasing the product into the processes of exchange.

In making this argument, Bylund also elucidates some common misconceptions which led to many other theories of the firm. The market, for example, is not a single

Henrique Schneider

hschneider@gmx.ch

1 Nordakademie, University of Applied Sciences, Köllner Chaussee 11, 23551 Elmshon, Germany 
institution, but it is a series of processes. In market processes, there is no homogeneity. There are heterogeneous market-agents, who strive themselves for ever more diversity. Their own preferences and means, for example capital and labor, are equally diversified and diversifying. In this setup, firms are heterogeneous channels for more heterogeneity. Market processes are the overall way for coordinating this heterogeneity.

Bylund proceeds systematically in several steps. He exposes the many mistakes of other theories of the firm in his first chapter, "What We Know and What We Don't Know about the Firm." He proceeds, then, to examine the market process in chapter two, "The Extent of the Market Process." In some other reviews of this book it has been remarked that this approach is particular, because Bylund does not assume a market in equilibrium. I, on the other hand, find this logical. Since the author envisages markets as heterogeneous processes, he could not have assumed equilibria. Remaining true to his own overall setup, Bylund examines the market as series of heterogeneous processes of exchange. There is, however, a particularly remarkable passage in this chapter. Bylund states: "In essence, exogenous changes cause price discrepancies that entrepreneurs exploit for profit" (p. 42). This statement - a part of which I will criticize later in this review - reveals a fundamental insight on market processes and on firms: Because of heterogeneity, markets are incomplete and firms are attempts in completing them.

This insight is deepened in chapter three, "The Specialization Deadlock." There, Bylund discusses which issues arise from the market processes being incomplete. The most important among them is what he calls "the specialization deadlock." Incumbent firms are already specialized. Because of their respective specializations, they have a place in a supply-chain, or chain of add-value. This place, however, is also a deadlock. These firms have neither the incentive nor the capacity to introduce something novel to the market. Their specialization makes them valuable in the supply chain but also traps them there. The entrepreneur-as-innovator, on the other hand, is not trapped in any supply chain. This agent can try to complete the market processes by introducing novel products to them. In order to do so, the entrepreneur-as-innovator engages in actions that have temporal consequences, i.e. actions with consequences that are not immediate. For innovating, the entrepreneur creates the new firm. In Bylund's words: "This [specialization deadlock] cannot be the case with productive innovations or production of previously unseen products. These must be implemented outside the extent of the existing exchange market" (p. 65). Or, in short: While incumbent firms are trapped in their supply chains in the market processes, novel firms complete the markets by introducing new supply chains to it.

The role of the entrepreneur as innovator and as a completer of market processes is further discussed in chapter four, "Entrepreneurship and Integration." The introducing of a new supply chain to the market processes is met with resistance. This arises from other market participants not being able, yet, to integrate the novel product. But it can also arise from market processes not being able to copy it to create the redundancies that abound in these processes. These are the reasons for innovative firms to be superspecialized. At least in the early stages of the novel product's lifecycle, only the innovator is specialized in the innovative product, only the innovator can integrate it into a chain of value-add. And yes, only the innovator can furnish the product explaining its relative scarcity, the frictions in furnishing or consuming it, and the "market power" of the innovator. 
Chapter 5 discusses "Authority and Hierarchy," heavily criticizing conceptions of the firm as primarily a form of hierarchy. Chapter 6, "The Volatile Character of the Firm," in turn, criticizes idealizing the firm as a coordination of legal contracts. Nor does the firm resemble economic planning. In fact, firms do have lifecycles. Imagining a firm as a hierarchy, a hub for legal contracts, or the plan of a central planner cannot accommodate lifecycles. Bylund, on the other hand, explains lifecycles but also the success and failure in the function of a firm in being able to channel its superspecialization into market processes or not.

Chapter seven is about "Firm Financing, Ownership, and Boundaries." Firms require upfront financing because they are only going to be repaid at the end of their innovation. Organizing a firm is a question of bridging time and uncertainty. Chapters eight and nine take on deeper analysis of "The Firm as a Market Institution" and "The Nature of the Market Process," respectively. Here, Bylund nuances the picture of the entrepreneur-as-innovator. He tries to accommodate incumbent firms, those in the specialization deadlock, by explaining them as former innovators that successfully integrated into supply chains. Chapter 10, "Policy Implications," and chapter 11, "What the Future Holds," give a practical and theoretical outlook.

I thoroughly enjoyed the book. I find it a fresh, coherent and consistent perspective in the idea of the firm and entrepreneurship. The main strength of Bylund's book is the integration of theories of entrepreneurship, innovation, the firm, and the market processes. In my opinion, regarding the firm as a vector for innovation through super-specialization convincingly reconciles managerial and economic discourses about the nature of the firm. For these reasons, I included the book into my syllabi including for introductory classes.

This being said, three remarks seem pressing. The first is a matter of style. Bylunds' intention of engaging with other theories of the firm is understandable; however, his constant remarks directed at other theories throughout the whole text make the book less readable (it also makes the book come across as pedantic). The second is a matter of content. As quoted before, Bylund sees the entrepreneur as an agent wanting to turn changes into opportunities and profit. Apparently, these changes happen due to exogenous factors. This, in my opinion, is highly disputable. Entrepreneurs do want to profit from changes and they take any exogenous change as an opportunity to do so. However, entrepreneurs also induce change themselves. They economize in the face of changing market processes so they can profit from it. In other words, there is also endogenous change. The third and final remark is a matter of expansion. The explanation for the firm that Bylund offers can also serve to better understand multi-sidednetworks. They, too, are islands of collaborative super-specialization and channels for completing heterogeneous market processes. Platforms, whether online or offline, deal in bridging time and uncertainty, and especially in constantly introducing new "addons" to their market processes. It would be valuable to use Bylund's framework to analyze them. Overall, I consider Bylund's monograph enlightening and would recommend it to people interested in economic theory but also managerial and strategic thinking. I also believe that it can be used as introduction into the topic.

Funding Open Access funding enabled and organized by Projekt DEAL. 
Open Access This article is licensed under a Creative Commons Attribution 4.0 International License, which permits use, sharing, adaptation, distribution and reproduction in any medium or format, as long as you give appropriate credit to the original author(s) and the source, provide a link to the Creative Commons licence, and indicate if changes were made. The images or other third party material in this article are included in the article's Creative Commons licence, unless indicated otherwise in a credit line to the material. If material is not included in the article's Creative Commons licence and your intended use is not permitted by statutory regulation or exceeds the permitted use, you will need to obtain permission directly from the copyright holder. To view a copy of this licence, visit http://creativecommons.org/licenses/by/4.0/.

Publisher's note Springer Nature remains neutral with regard to jurisdictional claims in published maps and institutional affiliations. 